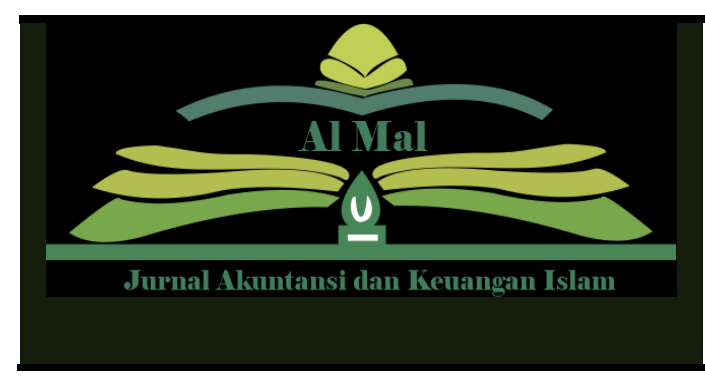

Al-Mal: JurnalAkuntansi dan Keuangan Islam E-ISSN: 2715-9477, P-ISSN: 2751-954X

Volume 03 Issue 01, 21 Januari 2021 Journal Page is available to: http:// ejournal.radenintan.ac.id/index.php/al-mal/index

\title{
Non Performing Finance: Bagaimana Pengawasan Pembiayaan di Baitul Maal Wa Tamwil?
}

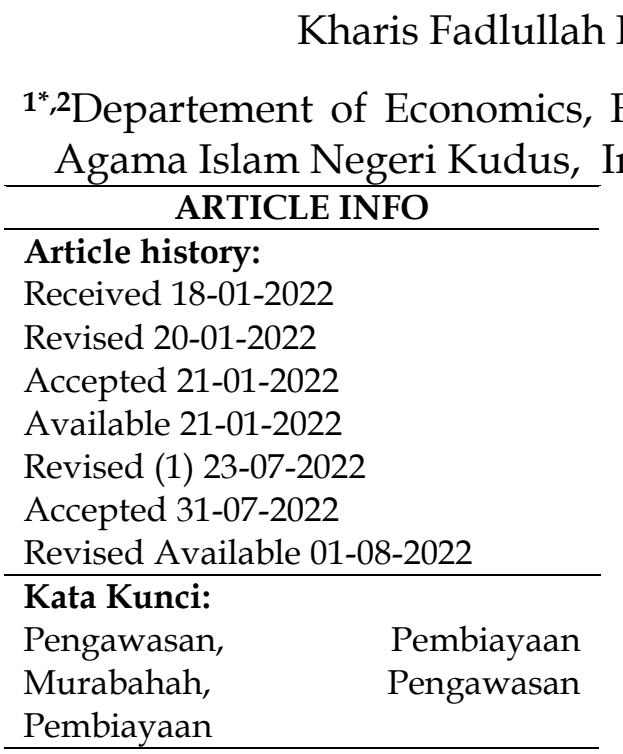

Paper type: Research paper

Please cite this article: Hana, K. F., \& Andriani, F. N. "Non Performing Finance: Bagaimana Pengawasan Pembiayaan di Baitul Maal Wa Tamwil?" Al-Mal: Jurnal Akuntansi dan Keuangan Islam [ONLINE\}, Volume 03 Number 01 (Januari 21, 2022)

Cite this document:

Al-Mal 2th edition

*Corresponding author

e-mail: kharis@iainkudus.ac.id

Page: 111-134 \begin{tabular}{lcl}
\hline \multicolumn{4}{c}{ ABSTRAK } \\
\hline Penelitian ini bertujuan untuk menganalisis
\end{tabular} bagaimana pengawasan pembiayaan di BMT Mubarakah Kudus, khususnya Pengawasan Pembiayaan Murabahah, Penilaian pengawasan pembiayaan Murabahah. Metode penelitian ini menggunakan pendekatan kualitatif dan menggunakan data primer, yaitu data yang diperoleh langsung dari lapangan, data ini didapat dari hasil observasi dan wawancara langsung. Kemudian data sekunder didapat dari buku-buku dan jurnal yang berkaitan dengan judul Analisis Pengawasan Pembiayaan. Hasil penelitian ini menyimpulkan bahwa Murabahah merupakan salah satu jenis pembiayaan yang ditawarkan oleh BMT Mubarakah Undaan Kudus. BMT Mubarakah Undaan Kudus melakukan kegiatan pengawasan pembiayaan murabahah yaitu pengawasan secara preventif dan pengawasan secara represif, analisis pengawasan pembiayaan murabahah pada BMT Mubarakah Kudus menggunakan analisis character, capital, capacity, collecteral, and condition (5C). Keterbatasan pada penelitian ini hanya berfokus pada objek penelitian yaitu BMT sehingga membuka peluang bagi peneliti yang lain untuk menambahkan objek yang lebih luas. Implikasi pada penelitian ini yaitu pembiayaan murabahah mempunyai peranan penting dalam perkembangan BMT Mubarakah Kudus, untuk menghindari pembiayaan bermasalah Pengawasan di BMT Mubarakah Undaan Kudus dengan menjalankan pengawasan langsung dan pengawasan administrative. Al-Mal with CC BY license. Copyright $\odot$ 2022, the author(s) 
ABSTRACT: This study aims to analyze how the supervision of financing at BMT Mubarakah Kudus, especially Murabahah Financing Supervision, Murabahah financing supervision assessment. This research method uses a qualitative approach and uses primary data, namely data obtained directly from the field, this data is obtained from direct observations and interviews. Then secondary data was obtained from books and journals related to the title Analysis of Financing Supervision. The results of this study conclude that Murabahah is one type of financing offered by BMT Mubarakah Undaan Kudus. BMT Mubarakah Undaan Kudus conducts monitoring activities for murabahah financing, namely preventive supervision and repressive supervision, analysis of murabahah financing supervision at BMT Mubarakah Kudus using character, capital, capacity, collecteral, and condition analysis (5C). The limitation of this study is that it only focuses on the object of research, namely BMT, thus opening up opportunities for other researchers to add wider objects. The implication of this research is that murabahah financing has an important role in the development of BMT Mubarakah Kudus, to avoid financing problems. Supervision at BMT Mubarakah Undaan Kudus by carrying out direct supervision and administrative supervision.

Keyword: Supervision, Murabaha Financing, Financing Supervision.

\section{PENDAHULUAN}

Dari tahun ketahun industri perekonomian di Indonesia semakin luas dan sangat bernilai. Kontribusi perusahaan semakin bertambah. Peranan sektor perusahaan berdampak besar terhadap keberlangsungan pertumbuhan ekonomi Indonesia (Mudrahat 2007).

Dalam perekonomian yang kita lalui saat ini, sektor perbankan memiliki peran yang kompleks. Hampir setiap perspektif kehidupan manusia tidak lepas dari perbankan dan Lembaga keuangan mikro.

Di Indonesia pertumbuhan bank Syariah atau Bank yang dikenal dengan Bank Syraiah atau Lembaga Mikro Syariah (LKMS), bukanlah hal baru. Sejak tahun 1992, organisasi keuangan Syariah telah berkembang, melarang penggunaan bunga (riba) dalam kegiatan operasionalnya. Larangan riba yang secara khusus dinatakan dalam Al-Quran merupakan salah satu faktor utama yang menyebabkan berdirinya bank Syariah atau Lembaga keuangan mikro Syariah. Riba adalah pengambilan tambahan yang terjadi baik dalam transaksi jual beli, maupun pinjam meminjam secara batil atau melanggar prinsip dalam syariat islam muamalah.

Baitul Maal Wat Tamwil (BMT) adalah sebuah koperasi, yang salah satu Lembaga keuangan mikro Syariah. BMT adalah organisasi yang beroperasi dengan paradigma "Baitul Tamwil dan Baitul Maal”, dengan tujuan utamanya pada sektor Usaha Kecil Menengah (UKM). Dalam melaksanakan kegiatan usaha produktif dan investasi, mempromosikan kegiatan tabungan, 
mendukung pembiayaan kegiatan ekonomi, terutama mengembangkan keutamaan ekonomi UKM dengan menerapkan konsep Baitul Tamwil.

Menurut fungsinya, BM bertugas menghimpun, mengelola dan menyalurkan dana ZIS (Zakat, Infak, Sedekah) sebagai bagian yang menitikberatkan pada aspek sosial. Sementara, BT merupakan lembaga komersial dengan pendanaan dari pihak ke tiga, bisa berupa pinjaman atau investasi (Muttaqin, 2012).

Pemberian pembiayaan berdasarkan Pasal 8 Undang-Undang Nomor 10 Tahun 1998 didasarkan pada analisis dan prinsip kehati-hatian, sehingga nasabah mampu membayar kewajibannya atau mengembalikan pembiayaan sesuai dengan kesepakatan, dan terhindar dari kemacetan pembayaran. (Karim, 2010)

Pembiayaan murabahah adalah jenis pembiayaan yang sering digunakan di BMT. Akad Murabahah adalah akad jual beli dimana nasabah bertindak sebagai pembeli dan bank bertindak sebagai penjual. Harga jual adalah harga beli ditambah pinjaman dari bank. Sebagian masyarakat tidak memahami pelaksanaan akad ini, walaupun akad murabahah ini kerap digunakan. Beberapa ketentuan yang harus dipenuhi dalam pelaksanaan akad murabahah agar transaksi akad tersebut terhindar dari riba dan sesuai dengan Syariah. Banyak anggapan bahwa praktik Lembaga keuangan Syariah tidak jauh berbeda dengan Lembaga keuang konvensional yang telah dikenal masyrakat luas sebelumnya. Produk yang dijual belikan merupakan salah satu syarat produk yang diakadkan. Pembiayaan murabahah merupakan pembiayaan yang bersifat certainly profit, artinya tingkat keuntungan yang di dapat oleh bank syariah relatif pasti dan bersifat konstan. Dibanding dengan pembiayaan yang lain, pembiayaan murabahah juga relatif kecil resikonya dan juga relatif mudah dalam perhitungan dan manajemennya (Latif, 2016). Selain itu, tingginya pembiayaan murabahah terjadi karena pembiayaan ini cenderung memiliki risiko yang lebih kecil dan lebih mengamankan bagi shareholder (Lukmanul Hakim \& Anwar, 2017).

Menurut Fatwa Dewan Syariah Nasional MUI No.04/DSN-MUI/IV/2000 tentang murabahah, Bank (BMT) harus terlebih dahulu membeli asset yang dimiliki secara sah oleh nasabah sebelum menawarkan asset kepada nasabah. Dalam akad murabahah, syarat objek yang menjadi objek, produk yang diperjualbelikan pada prinsipnya harus sudah menjadi milik bank (BMT). Jika menjual barang baru akan menjadi miliknya maka tidak sah. (Melina, 2020)

BMT Mubarakah Kudus adalah Lembaga keuangan Syariah yang menjalankan prinsip Syariah dalam operasionalnya. BMT Mubarakah Undaan Kudus memberikan pembiayaan murabahah yang bisa digunakan untuk 
penegmbangan usaha atau kegiatan konsumtif, pembelian kendaraan bermotor, yang diperlukan bisa membantu membebaskan masyarakat dari suku bunga yang ditentang syariat islam, serta bisa merancang pembiayaan sesuai dengan kebutuhan dan kemampuan nasabah. Sebelum pembiayaan, pengawasan dilakukan untuk mengurangi risiko yang mungkin timbul selama jangka waktu pembiayaan. Sementara itu pengawasan pasca pembiayaan dilaksanakan dengan tujuan untuk menjaga kualitas pembiayaan agar tetap berada pada kategori lancar. Oleh karena itu BMT Mubarakah harus memantau secara ketat pembiayaannya guna menekan pembiayaan bermasalah yang ada pada BMT tersebut.

\section{Pengawasan}

Kinerja Selain pemilihan pola pembayaran angsuran, yang berpengaruh terhadap penambahan pembiayaan adalah pengawasan pembiayaan yang dilakukan oleh pihak manajemen BMT itu sendiri (Hurun'in \& Nurrohman, 2020). Pengawasan atau monitoring sesuai dengan konsep pengawasan dalam arti luas, yaitu salah satu fungsi manajemen dalam menjaga dan mengamankan kekayaan bank dalam bentuk perkreditan yang lebih baik dan efisien agar tidak terjadi penyimpangan dengan berpedoman pada perkreditan yang telah ditetapkan serta kebijakan dan pengaturan administrasi kredit yang baik. Menurut Sondang P Siagian, pengawasan adalah upaya total untuk memantau pelaksanaan kegiatan operasionalnya untuk menjamin bahwa mereka mengikuti rencana yang ditentukan (Wicaksono, 2020).

Monitoring disebut juga sebagai alat untuk memonitor pembiayaan agar setiap penyimpangan yang terjadi dapat diidentifikasi sedini mungkin (early warning system) dan berdampak pada kualitas pembiayaan (Bungkes \& Sahyuli, 2021). Langkah-langkah untuk menghilangkan kerugian diperoleh sebagai akibat dari ini. Sementara itu, pengawasan pembiayaan dapat menjadi salah satu tanggung jawab manajemen yang bertujuan untuk menjaga dan mengelola pembiayaan sebagai sumber kekayaan, serta dapat menetapkan Panjang pinjaman dan asumsi sebagai dasar untuk mencapai kesepakatan atau mendeteksi pelanggaran. (Panetir Bungkes dan Sahyuli 2021) 
Tujuan pengawasan harus dinyatakan dengan jelas dengan mekanisme yang tepat agar dapat berfungsi secara efektif, bertujuan untuk memastikan bahwa sistem pembiayaan beroperasi dengan cara yang aman dan sehat sesuai dengan ajaran Islam (Syukron, 2012).

\section{Pengawasan Pembiayaan}

WBSCD Salah satu upaya untuk mengarahkan pembiayaan bank berdasarkan prinsip yang sehat adalah pengawasan pembiayaan. Pengawasan pembiayaan mencakup aspek pra-pembiayaan dan pasca-pembiayaan. Sebelum pembiayaan, pengawasan dilakukan untuk mengurangi risiko yang mungkin timbul selama jangka waktu pembiayaan. Tujuan dilakukannya pengawasan pembiayaan adalah untuk menjaga kualitas pembiayaan agar tetap pada lancar. (Waldi Nopiansyah, 2017)

Pengawasan merupakan langkah awal BMT dalam memberikan pembiayaan kepada anggota. Tidak hanya itu pengawasan juga meliputi pengawasan sebelum pembiayaan diberikan (steering control), pengawasan pada waktu proses persetujuan pembiayaan (post action control) dan pengawasan setelah pembiayaan diberikan (feedback control) (Fatimah \& Suharto, 2020).

Pengawasan pembiayaan adalah fungsi manajemen dalam upaya memastikan pengamanan dan pengelolaan bank kekayaan yang lebih baik dan efisien agar tidak terjadi penyimpangan yang mendorong kepatuhan terhadap kebijakan pembiayaan yang telah ditetapkan, atau fungsi pengawasan agar penyimpangan dapat terdeteksi sedini mungkin. (Rinda dan Arisandi 2019). Setiap pengurus atau pegawai yang menangani kegiatan dibidang pembiayaan pada masing-masing bank atau cabang bank bertanggungjawab untuk melaksanakan tugas pengawasan. Akibatnya pengawasan pembiayaan sudah melekat disetiap tingkat manajemen atau secara individu. (Sari, 2014a)

Pengawasan pembiayaan berpotensi mempermudah terjadinya penyimpangan yang berujung pada risiko dan pembiayaan bermasalah. Selain itu, akan memperkuat posisi bank dan debitur dalam menghadapi dimasa 
depan. Pengawasan BMT dalam melaksanakan kegiatan usaha disebutkan dalam pasal 1 angka 39 Peraturan Menteri Koperasi dan Usaha Kecil dan Menengah No. 11/Per/M.KUKM/XII/2017 (Ma'sum, 2018).

3. Pembiayaan Murabahah

Pembiayaan adalah kemampuian untuk melaksanakan suatu pembelian atau mengadakan suatu pinjaman dengan suatu janji pembayarannya akan ditangguhkan pada jangka waktu tertentu yang disepakati (Supriyadi \& Asnawi, 2019). Murabahah adalah akad jual beli dimana penjual mengumumkan harga belinya kepada pembeli terlebih dahulu, sebesar harga pokok produk ditambah margin yang disepakati antara para pihak. (Waldi Nopriansyah, 2017). Pembelian dengan pesanan dan pembelian tanpa pesanan adalah du acara untuk melakukan murabahah.(L. Hakim \& Anwar, 2017). Bai al-Murabahah adalah jual beli barang pada harga asal dengan tambahan keuntungan yang disepakati dalam Bai al Murabahah, penjual harus memberi tahu harga produk yang ia beli dan menentukan suatu keuntungan sebagai tambahannya (Rejeki, 2013). Secara sederhana, konsep murabahah diartikan sebagai suatu bentuk jual beli dengan adanya komisi atau suatu bentuk penjualan barang dengan harga awal ditambah keuntungan yang disepakati (Farid, 2013).

Pembiayaan murabahah pada BMT cenderung lebih dominan dibandingkan jenis pembiayaan lain seperti mudharabah dan musyarakah karena pihak yang menerima pembiayaan tidak perlu membuat laporan rutin penggunaan dana pembiayaan dan risiko yang diterima BMT lebih kecil (Rodiana et al., 2014). Pembiayaan murabahah digemari nasabah BMT karena karakternya profitable, mudah dalam penerapan, dan risk factor yang ringan untuk diperhitungkan. Dalam penerapannya, BMT bertindak sebagai pembeli sekaligus penjual barang halal yang dibutuhkan nasabah (Hanjani \& Haryati, 2018). Pembiayaan murabahah yang terdapat di lembaga keuangan syariah di Indonesia, termasuk BMT, menggunakan konsep murabahah Kepada Pemesanan Pembelian (KPP). Murabahah kepada Pemesan Pembelian (KPP) 
merupakan jual beli dengan akad murabahah yangmana pihak penjual tidak memiliki barang yang diminta oleh nasabah, lembaga keuangan hanya mengadakan barang untuk memenuhi kebutuhan nasabah yang memesannya (Wibowo, 2015).

Menurut Adiwarman Karim (2001), salah satu tanggungjawab utama bank adalah menyediakan layanan fasilitas pembiayaan yang sesuai dengan kebutuhan pihak yang dirugikan. Pembiayaan adalah istilah yang digunakan untuk menggambarkan proses peminjam uang. (Suryanto, Ratna Meisa, n.d.). Penjualan dan pembelian barang dengan harga asli ditambah keuntungan yang disepakati dikenal sebagai pembiayaan murabahah. Penjual harus mengetahui harga pokok produk yang dibeli dan memilih tingkat tertentu selain menjelaskannya kepada pembeli dalam jual beli. (Setiady, 2015)

Ketentuan murabahah juga diatur dalam Fatwa DSN No.04/SDSNMUI/IV/2000, yang menyatakan bahwa bank dan nasabah wajib melakukan akad murabahah bebas riba. Hukum islam tidak melarang penjualan atau pertukaran barang apapun. Bank memberikan kontribusi terhadap harga pembelian barang-barang yang kualitasnya telah disepakati, baik sebagian maupun seluruhnya. Atas nama bank, bank membeli barang yang diharapkan nasabah, dan pembeli ini harus legal dan bebas riba. Bank diharuskan untuk mengatasi hal-hal penting yang melibatkan pembelian, seperti jika barang dibeli secara kredit. (Efendi \& Thamrin, 2021)

Beberapa hal yang harus diperhatikan dalam pembiayaan murabahah, yaitu sebagai berikut (Afrida, 2016):

a. Penjual memberitahukan biaya modal kepada nasabah

b. Kontrak pertama harus sah sesuai dengan rukun yang ditetapkan

c. Kontrak harus bebas riba

d. Penjual harus menjelaskan kepada pembeli bila terjadi cacat atas barang sesudah pembelian

e. Penjual harus menyampaikan semua hal yang berkaitan dengan pembelian, misalnya jika pembelian dilakukan secara hutang 
Menurut Arifin, untuk mewujudkan visi misi dari lembaga keuangan syariah dalam hal pembiayaan maka diperlukan satuan kerja pembiayaan yang sehat meliputi: prosedur pembiayaan, prosedur administrasi, serta prosedur pengawasan pembiayaan (Sari, 2014).

\section{METODOLOGI PENELITIAN}

Penelitian ini menggunakan data kualitatif. Penelitian kualitatif adalah jenis penelitian yang menghasilkan data deskriptif tentang ucapan atau tulisan orang atau subjek, serta perilaku yang dapat diamati. BMT Mubarakah Undaan Kudus akan menjadi lokasi penelitian. Data primer dan data sekunder digunakan dalam penelitian ini. Data primer adalah informasi yang dikumpulkan dari sumber asli oleh peneliti. Data sekunder adalah informasi yang diperoleh dari mempelajari informasi yang ditemukan dalam buku atau dokumen tertentu. Data primer yang digunakan dalam penelitian ini yaitu melalui wawancara langsung dengan anggota administrasi dan pelayanan yaitu ibu Sad Nurul Islami. Wawancara langsung serta observasi digunakan sebagai Teknik pengumpulan data penelitian ini.

\section{HASIL DAN PEMBAHASAN}

Islam Untuk menghindari pembiayaan bermasalah serta guna menjamin pembiayaan maka pelaksanaan pengawasan pada BMT dilakukan secara kontinue. Pengawasan secara preventif dan pengawasan secara represif merupakan kegiatan pengawasan yang dilaksanakan oleh BMT Mubarakah Undaan Kudus.

1. Pengawasan Preventif

Prinsip kehati-hatian terhadap setiap prosedur pembiayaan, dari permohonan pembiayaan sampaai dengan pencairan pembiayaan merupakan bentuk pengawasan untuk menjaga terjadinya masalah dalam pembiayaan (Supriyadi \& Hana, 2021). 
Prosedur pembiayaan yang sehat yang harus ditempuh jika seseorang terlibat dalam pembiayaan meliputi, prosedur persetujuan pembiayaan, administrasi, dan pengawasan pembiayaan.

Dalam mengambil langak-langkah preventif BMT melakukan adanya pengawasan. Pihak BMT juga harus melaksanakan penyelamatan pembiayaan bagi nasabah yang menghadapi permasalah pembiayaan, hal ini disampaikan bagi seluruh nasabah tidak terkecuali. Pihak BMT Mubarakah Undaan Kudus akan membantu mencarikan solusi untuk nasabah jika terjadi permasalahan dengan melakukan kunjungan kepada nasabah yang dilaksanakan secara rutin setiap hari atau setiap bulan. Dari menemui nasabah maka dapat diketahui hal apa yang perlu mendapat petunjuk atau pembinaan. Jika nasabah mengalami pembiayaan bermasalah atau mengalami tunggakan dalam mengangsur maka pihak BMT Mubarakah Undaan Kudus akan melakukan telephon call kepada nasabah tersebut. Selain itu dengan adanya telephon call dapat mewujudkan hubungan positif antara pihak BMT dengan nasabahnya sebagai mitra BMT.

a. Administrasi Pembiayaan

Dalam memberikan pembiyaan pihak BMT perlu mengawasi secara detail dan rinci prosedur pembiayaannya dimulai dari pengajuan hingga pencairan kemudian pihak BMT akan bertindak jika terdapat nasabah yang melanggar kewenangannya.

Pengawasan yang dilaksanakan meliputi: dimulai saat proses pengajuan dengan mengecek kelengkapan persyaratan hingga pada tahap pencairan. Untuk memudahkan dalam melakukan review nanti, maka petugas administrasi juga harus memisahkan berkas tersendiri antara nasabah. Pengawasan dilakukan oleh CS atau administrasi pembiayaan. Menurut Kasmir, prosedur pembiayaan sebagai berikut:

1) Anggota mengajukan permohonan pembiayaan dengan menyerahkan berkas-berkas. 
2) CS memeriksa kebenaran dokumen, serta menyelidiki berkas pinjaman.

3) Wawancara adalah metode pengumpulan informasi dari calon peminjam untuk menentukan kemauan serta keperluan nasabah yang seharusnya.

4) Kegiatan on the spot dilakukan ditempat dengan menilai berbagai objek yang dijadikan usaha atau agunan.

5) Ketetapan pembiayaan dilaksanakan setelah dilakukannya rapat komite pembiayaan guna melaksanakan pemeriksaan yang makin lengkap dan mengevaluasi apakah usulan nasabah terealisasi atau tidak.jika permohonan pembiayaan ditolak, surat harus disampaikan kepada setiap pemohon.

6) Keputusan untuk memutuskan pembiayaan dilakukan dengan menandatangani akad pembiayaan, sehingga sebelum proses pencairan para anggota atau calon anggota akad pembiayaan harus dicairkan terlebih dahulu.

7) Selesainya pembiayaan.

8) Penyaluran. (Kasmir, 2007)

b. Penilaiaan Kelayakan Pembiayaan

Tujuan dari analisis pembiayaan adalah untuk menawarkan dana dengan menggunakan sumber saat ini. Untuk memeriksa calon debitur baru yang mendukung Lembaga perbankan, meminta bantuan biro kredir untutk memperoleh informasi. Selain menggunakan jasa agensi, perusahaan dapat secara mandiri memeriksa baik calon debitur lama maupun calon debitur lama menggunakan 5C (Hana et al., 2021), yaitu (character, capital, capacity, collacteral, condition), yaitu mengevaluasi calon nasabah dengan penjelasan seperti berikut ini :

1. Character

Yaitu sifat atau kepribadian pelanggan. Maksud dari analisis ini adalah untuk mengetahui sifat/watak nasabah pemohon kredit dan 
apakah mempunyai sifat/watak bertanggungjawab atas kredit yang diterimanya. Kesediaan nasabah untuk membayar dalam keadaan sulit dapat ditunjukkan dari sini. Jika nasabah, disisi lain tidak memiliki sifat untuk membayar, nasabah akan berusaha untuk membayar karena berbagai alasan. Melalui observasi, pengalaman, riwayat hidup,dan hasil wawancara nasabah, sifat/watak akan terungkapn dari latar belakang nasabah.

2. Capital

Analisis yang dilakukan untuk mengetahui kelayakan kredit nasabah. Pendapatan pribadi dapat digunakan untuk kredit konsumtif, sedangkan bisnis dapat dibiayai untuk kredit perdagangan atau produktif. Kemampuan ini harus dievaluasi agar bank terhindar dari kerugian. Kemampuan nasabah dapat ditentukan berdasarkan dokumen yang nasabah miliki, hasil konfirmasi dengan pihak yang berhak mengeluarkan surat tertentu (misalnya pendapatan seseorang), wawancara, atau perhitungan rasio keuangan.

3. Capacity

Mengevaluasi modal yang dimiliki nasabah dalam rangka pembiayaan kredit. Hal ini signifikan karena bank tidak akan mendanai kredit secara penuh. Ini membutuhkan kontribusi dana dari nasabah. Jika nasabah juga menginvestasikan dana dalam opersai ini, nasabah akan mempunyai rasa memiliki dan akan bekerja keras untuk memastikan bahwa usahanya berhasil dan mampu memenuhi kewajiban kreditnya.

4. Collacteral

Penerima pembiayaan yang diberikan oleh bank memiliki agunan. Collecteral merupakan agunan yang diitawarkan oleh calon nasabah untuk pembiayaan yang diajukan atau dikenal sebagai sumber dana cadangan jika pembiayaan tidak selesai. Nasabah yang tidak mampu melakukan pembayaran menyebabkan bank menjual agunan yang dihasilkan, yang kemudian digunakan sebagai sumber pembayaran 
pembiayaan. Nilai agunan sama dengan jumlah pembiayaan yang diberikan oleh bank kepeda penerima pembiayaan. Hal ini menunjukkan bahwa agunan yang ditawarkan kepada bank oleh calon nasabah harus bernilai sama dengan jumlah pinjaman.

5. Condition

Ini mengacu pada keadaan ekonomi atau usaha penerima pinjaman. Bank harus menganalisis bidang usaha nasabah dalam hubungannya dengan kondisi ekonomi untuk mengetahui dampat kondisi ekonomi terhadap usaha calon nasabah dimasa mendatang. (Kasmir, 2009)

c. Penilaiaan Kelayakan Pembiayaan di BMT Mubarakah

Pembiayaan dilakukan sesuai dengan prinsip 5C, seperti yang ditunjukkan dalam studi diatas (character, capital, capacity, collacteral, condition). BMT Mubarakah Kudus menggunakan analisis pembiayaan dengan 5C dalam panduan interview. BMT Mubarakah Undaan Kudus menggunakan prinsip 5C, yaitu proses pemberian nilai berdasarkan pedoman, untuk meninjau pengajuan pembiayaan anngota dengan melihat berbagai komponen 5C untuk melihat apakah pembiayaan itu layak untuk diberikan. Untuk memastikan bahwa pembiayaan yang diberikan tidak akan mengalami masalah oleh sebab itu penggunaan penilaian $5 \mathrm{C}$ menjadi aspek penting dalam proses pembiayaan.

Pada saat BMT Mubarakah Kudus menganalisis nasabah menggunakan prinsip 5C, berikut adalah hasilnya:

\section{Character}

Pihak ketiga, seperti tetangga, keluarga, teman, masyarakat sekitar, dan lain-lain yang memiliki hubungan dengan pemohon dengan cara berhadapan langsung dengan mereka yang terlibat dapat digunakan untuk menganalisis karakter anggota BMT Mubarakah Kudus.

BMT Mubarakah Kudus menilai karakter nasabah meliputi: nasabah yang bisa dipercaya, tetap memenuhi janji, jujur, memegang reputasi baik 
di masyarakat, peka social, dan membayar angsuran tepat waktu. Aspek karakter pembiayaan bermasalah pada BMT Mubarakah adalah salah satu contoh kasus pembiayaan bermasalah yang disebabkan sifat nasabah yang tidak pasti dan terkadang tidak menentu. Ketika anggota diminta membayar angsuran misalnya, mereka sering menunda pembayaran cicilan.

2. Capital

Tujuan evaluasi modal dari nasabah adalah untuk mengetahuo keadaan modal, sumber modal, dan penggunaan modal. Memiliki asset usaha berupa tanah, rumah, atau barang, mempunyai simpanan di bank atau koperasi, mempunyai tingkat keuntungan usaha yang wajar dibandingkan dengan kewajiban membanyar pembiayaan, dan pembiyaan digunakan untuk modal usaha atau barang, merupakan prosedur tersendiri yang dimiliki BMT Mubarakah dalam menilai nasabah.

3. Capacity

Capacity adalah kemampuan nasabah untuk membayar kembali pinjaman tersebut . BMT Mubarakah Kudus mengkaji kemampuan nasabah dalam mengelola usahanya untuk mengembalikan pinjaman.BMT Mubarakah dalam menilai kemampuan nasabah memperhatikan aspek pengembangan usaha sebagai berikut: usaha telah beroperasi minimal dua tahun, lokasi usaha dan tempat tingga tetap dan milik sendiri, bahan baku mudah, pemasaran yang baik, langganan tetap dengan tepat waktu pembayaran, perkembangan saha yang baik, dan kemampuan membayar kewajiban, baik usaha tersebut mempunyai utang kepada pihak lain.

Selain itu, BMT Mubarakah Kudus mengevaluasi kemampuan pembayaran calon nasabah pembiayaan, misalnya dengan menggunakan KK (Kartu Keluarga) guna melihat seberapa banyak calon nasabah yang memiliki anggota keluarga. Hal ini berdampak pada kemampuan untuk 
membayar karena semakin besar beban dalam angggota keluarga maka kemampuan membanyarnya semakin rendah sehingga kemampuan untuk membanyarnya mengakibatkan keterlambatan saat pembayaran.

4. Collecteral

Nasabah dinilai oleh BMT Mubarakah berdasarkan jaminan, yang meliputi : apakah suami atau istri sanggup menandatangani dokumen perjanjian pembiayaan, apakah ada jaminan yang cukup untuk jumlah pinjaman, dan apakah ada pihak lain yang menanggung pembiayaan. Jaminan tersebut berupa sepeda motor, mobil, sertifikat tanah, atau BPKB untuk sepeda motor atau mobil. Tetapi yang paling sering atau paling efektif yang biasa digunakan di BMT Mubarakah adalah dalam bentuk sertifikat.

5. Condition

Usaha calon nasabah harus berkembang. Artinya, ia bisa memenuhi kebutuhan hidup keluarganya, menutupi pengeluaran operasional usahanya, serta memperoleh manfaat dari hasil usahanya, sehingga bis menjadi tambahan modal untuk mengembangkan usahanya. Apalagi jika nanti mendapat pembiayaan dari BMT, usahanya bisa berkembang, dan nasabah bisa melunasi utangnya.

Karena pendapatan yang diterima setiap bulan tidak jelas, kadang0kadang bisa menurun sehingga menyebabkan anggota tidak mampu membayar cicilan, merupakan sebab dari pihak BMT kurang memperhatikan usaha nasabahnya.

Karena pendapatan yang diperoleh tiap bulan kurang menentu terkadang menghadapi penurunan yang dapat menjadikan anggota tidak dapat membayar angsuran disebabkan pihak BMT kurang memperhatikan usaha anggotanya. BMT Mubarakah Kudus mengelompokkan nasabah berdasarkan kualitas pembiayaan dengan kolektabilitas mulai dari anggota lancer, kurang lancar, diragukan, dan macet untuk mengetahui perkembangan nasabahnya. 
Berdasarkan informasi yang disajikan di atas, dapat disimpulkan bahwa analisis prosedur pembiayaan murabahah di BMT Mubarakah Undaan Kudus menunjukkan bahwa anggota yang ingin mengajukan pembiayaan wajib mengikuti prosedur yang diatur BMT Mubarakah Undaan Kudus, mulai dari wawancara hingga prosedur kunjungan tempat usaha nasabah oleh pihak BMT Mubarakah Undaan Kudus.

Setelah prosedur selesai, BMT Mubarakah Undaan Kudus memeriksa formulir aplikasi pembiayaan murabahah yang telah diisi oleh anggota nasabah. BMT Mubarakah menggunakan prinsip 5C (character, capacity, capital, collateral and condition) untuk menentukan apakah disetujui atau tidaknya permohonan pembiayaan bagi calon nasabah. Setelah komite pembiayaan BMT Murabahah menyetujui formulir yang diberikan calon nasabah, maka dibuatkanlah surat pembiayaan murabahah dengan akad murabahah, dan calon nasabah menandatanginya.

Dari pernyataan di atas dapat diuraikan bahwa peneliti memperoleh data dari BMT Mubarakah Kudus mengenai tata cara pengajuan pembiayaan murabahah dan membandingkannya dengan teori yang ada. Permohonan pembiayaan murabahah yang diajukan ke BMT Mubarakah Undaan Kudus dinyatakan baik, sebab prosedur yang diatur telah disusun secara sistematis mulai tahap wawancara hingga tahap kunjungan usaha, serta BMT Mubarakah berpedoman pada prinsip 5C dalam menetapkan persetujuan. Hasil temuan pada penelitian ini sejalan dengan temuan penelitian yang dilakukan oleh (Panjaitan \& Soemitra, 2021) yang mengemukakan bahwa Pada umumnya prosedur kelayakan pembiayaan di Bank Sumut Syariah Brigjen Katamso Medan menerapkan prinsip 5C dan Bank Sumut Syariah Brigjen Katamso Medan melakukan pengawasan kepada nasabah yang telah memperoleh pembiayaan murabahah dengan cara monitoring, yaitu marketing secara langsung mendatangi nasabah untuk menagih nasabah dan manganalisa bagaimana 
kelancaran usaha yang dijalankan oleh nasabah, dan memberikan wejangan kepada nasabah agar usaha yang dijalankan oleh nasabah semakin berkembang.

Sementara itu, menurut penelitian (Mauludin, 2020) mengemukakan bahwa salah satu upaya yang dilakukan oleh BRI Syariah Pare dalam meminimalkan moral hazard dalam pembiayaan murabahah ialah dengan menggunakan proses analisis 5C, yaitu character (karakter), capacity (kapasitas), capital (modal), collateral (jaminan), dan condition (kondisi).

\section{Pengawasan Represif}

Setelah pembiayaan terlaksana dan digunkana oleh anggota sampai pembiayaan berakhir, pengawasan dapat dilakukan dengan berbagai cara untuk memperbaiki masalah yang timbul dalam pembiayaan. Karena permasalahan kredit biasanya terjadi setelah pembiayaan dicairkan, pengawasan represif sangat penting bagi BMT.

Selesainya pembiayaan tidak berarti bahwa tugas BMT Mubarakah telah selesai. Melakukan pengawasan merupakan salah satu komponen utama yang dilakukan.

Pengawasan pembiayaan merupakan peran manajemen yang bertujuan guna menopang serta mengawasi pembiayaan sebagai sumber kekayaan. Secara umum, pengawasan administrative dan fisik merupakan dua jenis pengawasan yang dapat dibiayai. Menurut Sondang tindakan pengawasan adalah sebagai berikut:

a. Pengamatan langsung atau observasi manajemen memungkinkan untuk melihat bagaimana petugas operasional melaksanakan kegiatan dan memenuhi tugasnya. Teknik ini memiliki potensi dalam implementasi strategi untuk meningkatkan efisiensi dan efektivitas. Pengawasan langsung memiliki banyak manfaatnya, seperti mendapatkan informasi tidak hanya mengenai pelaksanaan berbagai kegiatan, tetapi juga dengan 
manajemen memungkinkan pelaksana untuk mengambil tindakan cepat jika diperlukan.

b. Supervisor yang secara langsung mengawasi tugas-tugas tersebut setiap hari memberikan laporan, baik lisan maupun tertulis.(Sondang, 2005).

3. Analisis Kegiatan pengawasan di BMT Mubarakah

Dari data di atas, dapat peneliti analisis kegiatan pengawasan yang dilaksanakan oleh BMT Mubarakah dapat dikelompokkan :

a. Pengawasan Aktif atau pengawasan langsung.

Pengawasan yang dilakukan BMT Mubarakah Undaan Kudus dengan melakukan pemeriksaan langsung ke lokasi usaha nasabah. Pemeriksaan ini berguna sebab memungkinkan BMT Mubarakah Undaan Kudus mengenal keadaan sebenarnya dari usaha nasabah yang dibiayai dengan pembiayaan. Dan yang melakukan pengawasan ini adalah bagian AO (bagian pemasaran). BMT Mubarakah Undaan Kudus dapat meninjau perkembangan nasabah atau mitranya jika mekanisme pembayaran pembiayaan dicicil setiap hari. Karena BMT Mubarakah mengunjungi mitra setiap harinya. Alhasil BMT Mubarakah memberikan pembinaan sekaligus memantau perkembangan ussaha nasabahnya. Pengawasan ini dikenal dengan istilah inspeksi on the spot, dan paling signifikan karena mampu meringankan BMT dalam melakukan tindakan preventif. Akibatnya, inspeksi on the spot perlu dilaksanakan bukan hanya dengan eksidentil namun juga harus dilakukan secara teratur. Ini untuk semua nasabah tanpa dibedakan kepada nasabah yang menghadapi kesulitas dalam pembiayaan, dan BMT juga wajib melaksanakan penyelamatan pembiayaan tersebut. Nasabah dikunjungi setiap hari atau setiap bulan, dan jika ada masalah, BMT Mubarakah Undaan Kudus dapat membantu nasabah dalam menemukan solusi untuk nasabah.

Dengan kata lain, BMT dapat menentukan apakah nasabah memerlukan saran atau pembinaan berdasarkan kunjungan ke lokasi nasabah. Pihak BMT Mubarakah Undaan Kudus juga dapat menghubungi 
nasabah jika nasabah mengalami keterlambatan dalam membayar cicilan. Selain itu, telepon dilakukan dalam rangka menjalin hubungan positif antara BMT dengan nasabah sbagai mitra BMT.

b. Pengawasan Administrasi

Yaitu jika BMT Mubarakah Undaan Kudus memberikan pembiayaan kepada nasabah, maka BMT Mubarakah Undaan Kudus harus mengawasi seluruh proses pembiayaan dari awal hingga akhir, sehingga pihak mana pun yang melanggar persyaratan dapat dideteksi dan segera ditangani.

Pengawasan yang dilaksanakan meliputi: Dimulai dari proses pengajuan dan pengecekan kebenaran persyaratan hingga mencapai tahap pencairan. Selain itu, petugas administrasi ini harus menyimpan berkas yang berbeda untuk setiap nasabah sehingga dapat dengan mudah ditinjau. CS atau administrasi pembiayaan bertanggungjawab atas pengawasan ini.

Berdasarkan informasi diatas, layak untuk mengkaji bagaimana BMT Mubarakah Undaan Kudus melakukan pengawasan terhadap pembiayaan murabahah melalui pengawasan langsung serta administrative. Pengawasan langsung dilaksanakan melalui meninjau tempat usaha nasabah, selain meninjau lokasi nasabah, BMT juga mengirimkan informasi kepada nasabah melalui sms atau telepon untuk mengingatkan mereka akan kewajibannya jika terjadi tunggakan. Sedangkan pengawasan administrasi adalah tindakan pengumpulan, menyusun, dan memeriksa data dan dokumen untuk kelengkapan nasabah yang diperlukan selama proses pembiayaan, seperti kartu tanda penduduk, izin perusahaaan, dan surat perjanjian pembiayaan,dll.

Dari pernyataan diatas dapat diuraikan bahwa peneliti memperoleh data dari BMT Mubarakah Kudus mengenai tata cara pengawasan pembiayaan murabahah dan membandingkannya dengan teori yang ada, pengawasan pembiayaan murabahah dapat dilakukan dengan baik di 
BMT Mubarakah Undaan Kudus karena dilakukan dengan kegiatan administratif hingga kegiatan usaha nasabah di lapangan. Hal ini akan memberikan informasi pada BMT Mubarakah tentang perkembangan pembiayaan murabahah yang telah disalurkan pada nasabah.

Berdasarkan hasil penelitian ini sejalan dengan penelitian yang dilakukan oleh (Firdaus et al., 2021) yang menyatakan bahwa analisis sharia compliance pada pembiayaan murabahah di BMT di Kabupaten Ogan Komering Ilir sudah sesuai dengan prinsip-prinsip Islam dan Fatwa DSN-MUI, dapat dilihat dari beberapa unsur telah sesuai dengan akad murabahah yang merupakan kegiatan jual beli antara pembeli (nasabah) dan penjual (BMT), dimana BMT membiayai keseluruhan atau sebagian barang yang akan dibeli nasabah dengan menambahkan keuntungan melalui kesepakatan antara kedua pihak dari perolehan harga barang tersebut.

Adapun, penelitian oleh (Ubaidillah, 2019) juga sejalan dengan penelitian ini yang mengungkapkan bahwa pembiayaan murabahah lil amir bis syira' yang diterapkan oleh BMT Sidogiri cabang Bondowoso sesuai dengan prosedur pembiayaan yang berlaku sehingga secara praktik segala kelengkapan dan persyaratan administrasi dapat dipenuhi dalam pengajuan pembiayaan akad tersebut.

Selain itu, penelitian oleh (Zulfikri et al., 2019) mengemukakan bahwa pihak BNI Syarah Cabang Bogor mampu menjaga menjaga angka NPF yang dimilikinya tidak melebihi ketentuan yang telah ditetapkan oleh Bank Indonesia. Hal ini membuktikan bahwa strategi penyelamatan pembiayaan bermasalah pada pembiayaan murabahah yang digunakan oleh BNI Syariah Cabang Bogor telah efektif untuk dilakukan.

\section{KESIMPULAN}

Permohonan pembiayaan murabahah yang diajukan ke BMT Mubarakah Undaan Kudus dinyatakan baik, sebab prosedur yang diatur telah disusun 
secara sistematis mulai tahap wawancara hingga tahap kunjungan usaha, serta BMT Mubarakah berpedoman pada prinsip 5C dalam menetapkan persetujuan. BMT Mubarakah Undaan Kudus melakukan pengawasan terhadap pembiayaan murabahah melalui pengawasan langsung serta administrative. BMT Mubarakah Kudus melaksanakan pengawasan pembiayaan murabahah dilakukan dengan baik karena dilakukan dengan kegiatan administratif hingga kegiatan usaha nasabah di lapangan.

\section{IMPLIKASI PENELITIAN}

Implikasi pada penelitian ini yaitu pembiayaan murabahah mempunyai peranan penting dalam perkembangan BMT Mubarakah Kudus, untuk menghindari pembiayaan bermasalah Pengawasan di BMT Mubarakah Undaan Kudus dengan menjalankan pengawasan langsung dan pengawasan administrative.

\section{REFERENSI}

Afrida, Y. (2016). Analisis Pembiayaan Murabahah Di Perbankan Syariah. Jebi (Jurnal Ekonomi Dan Bisnis Islam), 1(2), 155-166.

Bungkes, P., \& Sahyuli, M. (2021). Mekanisme Pengawasan Pembiayaan Murabahah Sebagai Upaya Meminimalisir Pembiayaan Bermasalah Pada PT Bank Syariah Mandiri Kantor Cabang Pembantu (Kcp) Takengon. Jurnal Penelitian Ekonomi Akuntansi (JENSI), 5(1), 68-75. https:/ / doi.org/10.33059/jensi.v5i1.3519

Efendi, R., \& Thamrin, H. (2021). Pembiayaan Murabahah Di Pt. Federal International Finance Syariah Pekanbaru. Jurnal Tabarru': Islamic Banking and Finance, 4(1), 26-37. https:/ / doi.org/10.25299/jtb.2021.vol4(1).6057

Farid, M. (2013). Murabahah Dalam Perspektif Fikih Empat Mazhab. Epistemé: Jurnal Pengembangan Ilmu Keislaman, 8(1), 113-134. https:/ / doi.org/10.21274/ epis.2013.8.1.113-134

Fatimah, S., \& Suharto, T. (2020). Pengawasan dan Pembinaan Pembiayaan 
Murabahah Bermasalah di KSPPS BMT Husnul Aulia Ciledug. BANCO: Jurnal Manajemen Dan Perbankan Syariah, 2(1), 81-94. https://doi.org/10.35905/banco.v2i1.1001

Firdaus, A., Maftukhatusolikhah, \& Sumantri, R. (2021). Implementasi Kepatuhan Syariah (Syariah Compliance) Produk Murabahah Pada Baitul Maal Wa Tamwil (BMT) Di Kabupaten Ogan Komering Ilir. Syntax Idea, 3(5), 976-995.

Hakim, L., \& Anwar, A. (2017). Pembiayaan Murabahah Pada Perbankan Syariah Dalam Perspektif Hukum Di Indonesia. Al-Urban, 1(2), 212-223. https://doi.org/10.22236/alurban

Hana, K. F., Ridwan, \& Chodlir, E. A. (2021). Elaborasi Analisis Pembiayaan Dalam Meminimalisir Non Permorming Finance (NPF) Pada Lembaga Keuangan Syariah. Malia: Journal of Islamic Banking and Finance, 5(2), 121132.

Hanjani, A., \& Haryati, D. A. (2018). Mekanisme Pembiayaan Murabahah Pada Nasabah di Baitul Maal Wa Tamwil Universitas Muhammadiyah Yogyakarta. Jati: Jurnal Akuntansi Terapan Indonesia, 1(1), 46-51. https://doi.org/10.18196/jati.010105

Hurun'in, S. Z., \& Nurrohman. (2020). Pengaruh Pola Pembayaran Angsuran dan Pengawasan Pembiayaan Murabahah terhadap Laba Usaha Pedagang Kecil: Penelitian pada Koperasi Jasa keuangan Syariah BMT El-Tazkiyah Bandung. 2800.

Karim, A. (2010). Bank Islam Analisis Fiqih dan Keuangan. PT Grafindo Persada. Kasmir. (2007). Bank dan Lembaga Keuangan Lainnya (Cetakan IV). PT Raja Grafindo.

Kasmir. (2009). Pengantar Manajemen Keuangan (Kedua). Kencana.

Kunci, K., \& Pemikiran, D. (2017). Pendekatan Akad Murabahah Di Perbankan Syariah. 2(7), 15-24.

Latif, A. (2016). Implementasi Fatwa DSN-MUI Terhadap Praktik Pembiayaan Murabahah Bank Syariah Mandiri dan Bank Muamalat KCP Ponorogo. 
Muslim

Heritage,

$1(1)$,

$1-18$.

https:/ / doi.org/10.21154/muslimheritage.v1i1.379

Ma'sum, A. (2018). Kedudukan Baitul Mal Wa Tamwil Dalam Akad PPembiayaan Murabahah Di Daerah Istimewa Yogyakarta. Jurnal Pranata, 1(1), 22-32.

Mauludin, M. S. (2020). Analisa Manajemen Resiko Untuk Mengurangi Moral Hazard Nasabah Pembiayaan Murabahah BRI Syariah Pare. El-Faqih: Jurnal Pemikiran Dan Hukum Islam, 6(2), 75-97.

Melina, F. (2020). Pembiayaan Murabahah Di Baitul Maal Wat Tamwil (Bmt). Jurnal Tabarru': Islamic Banking and Finance, 3(2), 269-280. https://doi.org/10.25299/jtb.2020.vol3(2).5878

Muttaqin, A. (2012). Model Pembiayaan Baitul Maal Wa Tamwil dan Peranannya Dalam Pembinaan Kesejahteraan Usaha Kecil Menengah (UKM). Jurnal Humanity, 7(2), 35-45.

Panetir Bungkes, \& Sahyuli, M. (2021). Mekanisme Pengawasan Pembiayaan Murabahah Sebagai Upaya Meminimalisir Pembiayaan Bermasalah Pada Pt. Bank Syariah Mandiri Kantor Cabang Pembantu (Kcp) Takengon. Jurnal Penelitian Ekonomi Akuntansi (JENSI), 5(1), 68-75. https:/ / doi.org/10.33059/jensi.v5i1.3519

Panjaitan, F., \& Soemitra, A. (2021). Analisis Pembiayaan Dengan Prinsip Murabahah Pada PT Bank Sumut Syariah Cabang Medan. Jurnal Ilmiah Manajemen Dan Kewirausahaan, 1(2), 87-91. https://doi.org/10.51903/imk.v1i2.91

Rejeki, F. Y. S. (2013). Akad Pembiayaan Murabahah Dan Praktiknya Pada Pt Bank Syariah Mandiri Cabang Manado. Lex Privatum, 1(2), 19-31.

Rinda, R. T. K., \& Arisandi, N. (2019). Mekanisme Pengawasan Pembiayaan konsumtif pada PT. Bank negara indonesia syariah (persero) T. Kantor cabang pajajaran bogor. Moneter: Jurnal Keuangan Dan Perbankan, 7(2), 53. https:/ / doi.org/10.32832/moneter.v7i2.2518

Rodiana, N., Nuryartono, N., \& El Ayyubi, S. (2014). Efektivitas Penerapan 
Bayar Pascapanen pada Pengembalian Pembiayaan Akad Murabahah Pertanian Padi di Baitul Maal wa Tamwil As Salam, Kramat, Demak. AlMuzara'ah, 2(1), 17-38. https:// doi.org/10.29244/jam.2.1.17-38

Sari, N. (2014). Model Pengawasan Pembiayaan di BMT Mujahidin Pontianak.

Muqtasid: Jurnal Ekonomi Dan Perbankan Syariah, 5(1), 23-52. https:/ / doi.org/10.18326/muqtasid.v5i1.23-52

Setiady, T. (2015). Pembiayaan Murabahah Dalam Perspektif Fiqh Islam, Hukum Positif Dan Hukum Syariah. FIAT JUSTISIA:Jurnal Ilmu Hukum, 8(3), 517-530. https:// doi.org/10.25041/fiatjustisia.v8no3.311

Supriyadi, \& Hana, K. F. (2021). Desain Advokasi Penyelesaian Pembiayaan

Bermasalah Pada Baitul Maal Wa Tamwil. Equilibrium: Jurnal Ekonomi Syariah, 9(2), 445-466.

Supriyadi, S. G., \& Asnawi, A. (2019). Pembiayaan Akad Murabahah Pada Pt.

Amartha Mikro Fintek Cabang Trawas-Mojokerto. Seminar Nasional Sistem Informasi (SENASIF), 3(1), 1685-1693.

Suryanto, Ratna Meisa, evi N. (n.d.). Pembiayaan Murabahah Bermasalah (Studi Kasus Bank Pembiayaan Rakyat Syariah di Kota Bandung). Jurnal Ilmu Keuangan Dan Perbankan, 53-54.

Syukron, A. (2012). Pengaturan dan Pengawasan pada Bank Syariah. Economic: Jurnal Ekonomi Dan Hukum Islam, 2(1), 22-41.

Ubaidillah. (2019). Mekanisme Pembiayaan Murabahah Lil Amir Bis Syira' di Baitul Maal Wa Tamwil Sidogiri Cabang Bondowoso. 4(2), 1-16.

Wibowo, E. (2015). Manajemen Risiko Pembiayaan Murabahah di BMT Amanah Ummah. Al Tijarah, 1(2), 115-133. https://doi.org/10.21111/tijarah.v1i2.951

Wicaksono, J. W. (2020). Sistem Pengawasan Pembiayaan Bagi Hasil Lembaga Keuangan Syariah. Dinar: Jurnal Prodi Ekonomi Syariah, 4(September 2020), 1-22.

Zulfikri, A., Sobari, A., \& Gustiawati, S. (2019). Strategi Penyelamatan Pembiayaan Bermasalah Pada Pembiayaan Murabahah Bank BNI 
Syariah Cabang Bogor. Al Maal: Journal of Islamic Economics and Banking, 1(1), 65-78. https://doi.org/10.31000/almaal.v1i1.1776 